Z. Klin. Chem. Klin. Biochem.

12. Jg. 1974, S. 459-463

\title{
Serum-Desoxyribonucleasen und DNA-Antikörper bei Lupus Erythematodes
}

\author{
Von E. J. Zöllner, B. Heicke und R. K. Zahn
}

Physiologisch-Chemisches Institut der Johannes Gutenberg Universität Mainz

(Eingegangen am 3. Januar/16. Juni 1974)

Im Serum von 27 Patienten mit Lupus erythematodes visceralis (LE) ${ }^{1}$ ) wurde die Enzymaktivität der Desoxyribonuclease (DNase) ${ }^{1}$ ) (EC 3.1.4.5) gemessen und mit dem radioimmunologisch bestimmten anti-DNA-Antikörpergehalt der gleichen Serumprobe verglichen. Durch DNase-Aktivitätsmessungen in Seren mittels Adsorption von ${ }^{3} \mathrm{H}-\mathrm{DNA}$ an Nitrocellulose-Membranfilter nach Inkubation dieser ${ }^{3}$ H-DNA mit dem jeweiligen Serum konnten keine signifikanten Enzymaktivitätsunterschiede zwischen Seren mit hohen und solchen mit niedrigen anti-DNA-Antikörper-Titcrn festgestellt werden. Wird die enzymatische Aktivitätsbestimmung im DNA-Polyacrylamid-Gel nach Auftrennung des zu untersuchenden Serums mit Hilfe der Mikro-Disc-Elektrophorese durchgefüht (wobei durch diesen Trennschritt im Serum vorhandene DNase-Inhibitoren entfernt werden), so zeigt sich, daß LE-Seren mit hohem anti-DNAAntikörper-Titer niedrige Desoxyribonuclease-Aktivität und solche mit geringen oder fehlenden anti-DNA-Antikörper-Titern hohe Desoxyribonuclease-Aktivität aufweisen. Dieser statistisch signifikante Zusammenhang zwischen Desoxyribonuclease-Aktivität und anti-DNA-Antikörper-Titer bei Lupus ery thematodes wird sowohl im Hinblick auf methodische Interferenz bei der anti-DNA-Antikörper-Bestimmung als auch auf einen möglichen Einfluß von Desoxyribonucleasen bei der Induktion von DNA-Antikörpern diskutiert.

\section{Serum deoxyribonucleases and DNA-antibodies in lupus erythematodes}

The enzyme activity of deoxyribonuclease (DNase) (EC 3.1.4.5) was measured in the sera of 27 patients with systemic lupus erythematodes (LE). Comparison was made with the concentration of anti-DNA-antibodies determined by radioimmunoassay in the same serum. Measurements of DNase-activity by absorption on nitrocellulose filters of ${ }^{3} \mathrm{H}$-DNA following incubation with whole serum did not show any significant difference in enzyme activity between sera of patients with high or low anti-DNA-antibodies values. However, if the measurement of DNase-activity was performed in DNA-polyacrylamide-gel following separation of the serum by micro-disc-electrophoresis (which removes DNase-inhibitors present in most sera) a statistically highly significant correlation can be seen. LE-sera with high anti-DNA-antibody contents had a low DNase-activity and sera with low or even absent anti-DNA-antibody contents had high DNase-activity. These results are discussed with regard to the influence of deoxyribonuclease activity on DNAantibody determinations in vitro and on the induction of DNA-antibodies in vivo.

Bei der Diagnose des Lupus ery thematodes (LE) spielt die Bestimmung von Autoantikörpern eine besondere Rolle $(1,2,3)$. Hierbei sind es neben den sogenannten antinukleären Faktoren insbesondere Antikörper gegen Desoxyribonucleinsäure, die in letzter Zeit immer mehr an Bedeutung gewinnen $(4,5)$. Es konnte gezeigt werden, daß zwischen dem Nachweis von Antikörpern gegen dieses biochemisch klar definierte Antigen und dem Vorliegen eines LE ein eindeutiger Zusammenhang besteht $(6,7)$. Hierbei muß aber beachtet werden, daß DNA spaltende Enzyme, DNasen ${ }^{1}$ ), ubiquitär im Organismus verbreitet sind. Auch im Blut können sie nachgewiesen werden $(8,9,10)$. Ein Einfluß dieser Enzyme auf die Bildung und/oder den Nachweis von DNA-Antikörpern ist auf verschiedene Weise denkbar. So könnte einerseits die Bildung von Antikörpern in vivo dadurch beeinflußt werden, daß unter der Wirkung DNA-abbauender Enzyme die Immunogenität der DNA beeinflußt wird. Andererseits sind auch Reaktionen möglich, die in vitro nur die Messung.vorhandener DNA-Antikörper

\footnotetext{
1) Abkürzungen:

$\mathrm{LE}=$ Lupus erythematodes $\quad$ DNase $=$ Desoxyribonuclease
}

im Serum beeinflussen. Wie von Geisert et al (11) nachgewiesen wurde, steigt die Nachweisempfindlichkeit von DNA-Antikörpern mit dem Molekulargewicht der zugesetzten DNA. Durch die beim radioimmunologischen Nachweis übliche einstündige Inkubation bei $37^{\circ} \mathrm{C}$ bei einem pH-Wert, bei dem auch Serum-DNasen aktiv sind, könnte es bei hoher DNase-Aktivität des zugesetzten Serums zu einem Abbau der eingesetzten ${ }^{3}$ H-DNA kommen. Dadurch könnten die Reaktionen vorhandener Antikörper mit dem zugesetzten Antigen beeinflußt und falsche niedrige Werte vorgetäuscht werden.

Um den Zusammenhang zwischen DNase-Aktivität und DNA-Antikörpergehalt im Serum beurteilen zu können, bestimmten wir die DNase-Aktivität im Serum von LEPatienten, die einen unterschiedlichen Gehalt an DNAAntikörpern aufwiesen. Aufgrund der hohen Empfindlichkeit und der Möglichkeit, DNase-Aktivitäten auch beim gleichzeitigen Vorliegen von Inhibitoren im Untersuchungsmaterial zu beurteilen, kommt dabei dem micro-disc-elektrophoretischen DNase-Nachweis in DNAPolyacrylamidgelen eine besondere Bedeutung zu. 


\section{Material und Methoden}

\section{Untersuchungsmaterial}

Als Untersuchungsmaterial wurden Seren von 27 Patienten mit der klinisch und bioptisch gesicherten Diagnose Lupus erythematodes visceralis (LE) verwendet. Das Serum wurde auf übliche Weise gewonnen und bei $-20^{\circ} \mathrm{C}$ aufbewahrt.

\section{Chemikalien}

Herings-DNA wurde nach der Hitze-Detergens-Methode präpariert (12). Bei der radioaktiven DNA handelte es sich entweder um Tritiummarkierte $E$. coli-DNA mit einer spezifischen Aktivität von $4,7 \mu \mathrm{Ci} / \mathrm{mg}$ DNA, oder um ${ }^{14} \mathrm{C}$-DNA aus $E$. coli mit einer spezifischen Aktivität von $39,2 \mu \mathrm{Ci} / \mathrm{mg}$ DNA. Die radioaktive DNA wurde jeweils aus einer Thyminmangelmutante von $E$. coli ( $\left(\mathrm{R}\right.$ 34/K 416 thy $\left.^{-}\right)$, die in einem synthetischen Medium unter Zusatz von [Methyl- $\left.{ }^{3} \mathrm{H}\right]-$ Thymin oder $\left[2-{ }^{14} \mathrm{C}\right]-$ Thymin 6 Stunden wuchsen, isoliert. Dazu wurden die Bakterien geerntet und mit Lysozym ( $5 \mathrm{~g} / \mathrm{l})$ in einem Puffer lysiert. Die DNA wurde daraus durch wiederholte Fällung mit dem kationischen Detergens Cetyltrimethylammoniumbromid isoliert und gereinigt (13). Die analytischen Daten werden an anderer Stelle publiziert (7). [Methyl- ${ }^{3} \mathrm{H}$ \}-Thymin (spez. Aktivität 5,0 Ci/ mmol) und $\left[2{ }^{-14}-\mathrm{C}\right]$-Thymin (spez. Aktivität $60 \mathrm{mCi} / \mathrm{mmol}$ ) wurden vom Radiochemical Centre, Amersham, bezogen. Alle anderen Chemikalien waren vom höchsten käuflichen Reinheitsgrad.

\section{DNase-Bestimming}

\section{Gesamtaktivität}

Die Bestimmung der DNase-Gesamtaktivität erfolgte durch Messung der Adsorption von ${ }^{3} \mathrm{H}$-DNA an Nitrocellulosefiltern nach vorangegangener Inkubation einer ${ }^{3} \mathrm{H}$-DNA Lösung mit Serum (14).

Die Methode beruht darauf, daß Nitrocellulosefilter nur relativ große Polynucleotidstränge adsorbieren. Der Versuchsansatz $(0,5 \mathrm{ml})$ enthielt $5 \mu \mathrm{mol}$ Tris-HCl-Puffer $\mathrm{pH} 7,5 ; 1,5 \mu \mathrm{mol}$ $\mathrm{MgCl}_{2} ; 3 \mu \mathrm{g}{ }^{3} \mathrm{H}$-DNA aus $E$. coli (spez. Aktivität $4,7 \mu \mathrm{Ci} / \mathrm{mg}$ DNA) und $0,1 \mathrm{ml} \mathrm{Serum}$. Der Testansatz wurde dazu $15 \mathrm{Minu}-$ ten bei $37^{\circ} \mathrm{C}$ inkubiert. Nach Zugabe von $0,5 \mathrm{ml} 0,15 \mathrm{~mol} / 1$ $\mathrm{NaCl}, 15 \mathrm{mmol} / 1 \mathrm{NaCitrat}$ wurde der Ansatz 5 Minuten im siedenden Wasserbad erhitzt, abgekühlt und $15 \mathrm{ml} 10 \mathrm{mmol} / \mathrm{l}$ Tris-HCl-Puffer $\mathrm{pH} 7,5,0,5 \mathrm{~mol} / 1 \mathrm{KCl}$ zugegeben. Diese Lösung filtrierten wir durch Nitrocellulose-Membranfilter (Schleicher und Schüll, Typ A, Grade B6). Daraufhin wurde mit $50 \mathrm{ml}$ $0,5 \mathrm{~mol} / 1 \mathrm{KCl}-10 \mathrm{mmol} / 1$ Tris- $\mathrm{HCl} \mathrm{pH} 7,5$ nachgespült. Die Filter wurden in $1 \mathrm{ml}$ 2-Äthoxyäthanol bei Raumtemperatur aufgelöst und nach Zugabe von $10 \mathrm{ml}$ Aquasol-Scintillator (NEN) in einem Flüssigkeitsscintillationszähler gezählt. Die Aktivität wurde in \% DNA angegeben, die nach erfolgter Inkubation nicht mehr an Nitrocellulosefilter adsorbiert wurde. Sie wurde nach folgender Formel berechnet $\frac{T-F}{T} \times 100=\%$ nicht adsorbierte DNA, wobei $T$ die Gesamtaktivität der eingesetzten ${ }^{3} \mathrm{H}$-DNA in Imp./min, F der Radioaktivität (in Imp./min) auf dem Filter entspricht.

In Vergleichsversuchen mit DNase I (spezifische Aktivität: 2500 Einheiten $/ \mathrm{mg}$ ) wurde mit dieser Methode eine Proportionalität zwischen \% nichtadsorbierter DNA und eingesetzter DNase I über einen Bereich von $5 \mu \mathrm{g} / 1$ bis $50 \mu \mathrm{g} / 1$ festgestellt.

\section{Bestimmung von DNase I-Inhibitoren im Serum}

Den Nachweis von DNase-Inhibitoren in LE-Seren führten wir mittels Bestimmung der DNase-Aktivität durch Messung der Extinktion des säurelöslichen Überstandes bei $260 \mathrm{~nm}$ nach Inkubation einer Herings-DNA-Lösung mit dem jeweiligen Serum in Parallelansätzen mit und ohne DNase I aus (15). Die Ansätze enthielten $3 \mathrm{ml} \mathrm{0,1} \mathrm{mol} / 1$ Tris-HCl-Puffer $\mathrm{pH} 7,4,10 \mathrm{mmol} / 1$ $\mathrm{MgCl}_{2}, 1 \mathrm{mmol} / 1 \mathrm{CaCl}_{2}, 0,1 \mathrm{ml}$ DNase I $(0,1 \mathrm{mg} / \mathrm{l})$ und jeweils $0,1 \mathrm{ml}$ Serum oder $0,15 \mathrm{~mol} / 1 \mathrm{NaCl}$. Die Inkubation erfolgte bei $37^{\circ} \mathrm{C}$. Die Reaktion wurde nach $15 \mathrm{~min}$ und $30 \mathrm{~min}$ durch $\mathrm{Zu}$ gabe von $1,5 \mathrm{ml}$ kalter Perchlorsäure $(250 \mathrm{~g} / 1)$ abgestoppt, die Ansätze $25 \mathrm{~min}$ im Eisbad stehengelassen und dann bei $4{ }^{\circ} \mathrm{C}$
20 min mit $7000 \mathrm{U} / \mathrm{min}$ (Sorvall Rotor SM 24) zentrifugiert. Die Extinktion der Überstände bei $260 \mathrm{~nm}$ wurde gemessen und auf die Extinktionszunahme serumfreier Kontrollen bezogen.

\section{Disc-Elektrophorese}

Die Auftrennung und Bestimmung der DNase-Aktivitäten im Serum - vor allem im Hinblick' auf die beschriebenen DNaseInhibitoren - erfolgte außerdem mit einer micro-disc-elektrophoretischen Technik (16) basierend auf Angaben von Boyd. \& Mitchell (17) und Neuhoff (18). Das Zwischengel (pH 6,7) enthielt $50 \mathrm{~g} / 1$ Acrylamid und das Trenngel $(\mathrm{pH} \mathrm{8,8)} 134 \mathrm{~g} / 1$ Acrylamid. Die Elektrophorese wurde mit $700 \mu \mathrm{A} / \mathrm{Gel}$ für 90 Minuten in anodischer Laufrichtung bei $0^{\circ} \mathrm{C}$ durchgefürt. Das Trenngel enthielt $0,3 \mathrm{~g} / 1$ Herings-DNA. $8 \mu 1$ des $1: 2 \mathrm{mit}$ Saccharose $(300 \mathrm{~g} / \mathrm{l})$ in $0,16 \mathrm{~mol} / \mathrm{l} \mathrm{Zwischengelpuffers} \mathrm{verdünn-}$ ten Serums wurde aufgegeben. Nach dem Lauf wurden die Gele

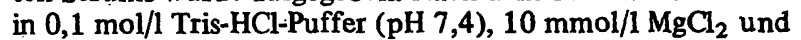
$1 \mathrm{mmol} / 1 \mathrm{CaCl}_{2}$ vier Stunden bei $37^{\circ} \mathrm{C}$ inkubiert und dann mit Gallocyanin-Chromalaun angefärbt. Nach der Differenzierung mit $\mathrm{H}_{2} \mathrm{O}$ finden sich proportional der Desoxyribönuclease-Aktivität Zonen, die infolge ihres DNA-Verlustes weniger oder überhaupt nicht angefärbt sind. Zur Auswertung wurden die Gele densitometrisch vermessen (Mikrograph DD 5 Kipp und Zonen, Delft/Holland).

Zum DNase-Nachweis mit ${ }^{3} \mathrm{H}-\mathrm{DNA} \mathrm{A}^{-}$Polyacrylamidgelen verwendeten wir Trenngele aus dem oben beschriebenen Elektrophoresesystem. An Stelle der Herings-DNA enthielten die Trenngele jedoch $0,3 \mathrm{~g} / 1^{3} \mathrm{H}-\mathrm{DNA}$ aus $E$. coli. Nach Beendigung der Elektrophorese wurden die Gele in 1,5 $\mu$ l große Scheiben geschnitten, jede Scheibe in jeweils $200 \mu$ l Puffer vier Stunden inkubiert und die Radioaktivität in der Inkubationslösung gemessen. Sie stellt ein Maß für die DNase-Aktivität dar (10).

Zur Standardisierung des DNase Nachweises im Polyacrylamidgel sowohl mit Herings-DNA als auch mit ${ }^{3} \mathrm{H}$-DNA aus $E$. coli wurde DNase I aus Rinderpankreas (Worthington, Freehold, USA, spezifische Aktivität: 2500 Einheiten $/ \mathrm{mg}$ ) benutzt.

Im Fall der Herings-DNA-Gele wurden dabei unterschiedliche Konzentrationen an DNase der Elektrophorese auf DNA-haltigen Gelen unterworfen und die Gele wie oben beschrieben entwickelt und densitometrisch vermessen. Die planimetrierten Ausschläge der Densitometerkurven wurden dann zu denen der jeweiligen Proben in Beziehung gesetzt, wobei nur solche Eichgele zum Vergleich herangezogen wurden, deren Aktivität von der gleichen Größenordnung wie die zu erwartende Bande war. Die DNase-Aktivität der Serumproben wurde dann in $\mu \mathrm{g} / \mathrm{l}$ angegeben, also bezogen auf eine DNase I-Konzentration, die eine äquivalente Aktivität in diesem Nachweissystem aufwies.

Die Standardisierung des DNase-Nachweises in ${ }^{3} \mathrm{H}-\mathrm{DNA}$-Polyacrylamidgelen wurde ähnlich durchgeführt, nur daß hier nicht die planimetrierten Densitometerausschläge, sondern die durch äquivalente Konzentrationen an DNase I aus den Gelen freigesetzte Radioaktivität zum Vergleich herangezogen wurdẹ.

\section{DNA-A ntikörper-Bestimmung}

Die Bestimmung der DNA-Antikörper erfolgte radioimmunologisch mit der von Heicke \& Lemmel beschriebenen Methodik $(6,7)$. Sie beruht darauf, daß nach Inkubation einer ${ }^{14}$ C-DNALösung mit einem Serum, es nach der Reaktion darin vorhandener Antikörper mit der radioaktiven DNA bei Halbsättigung mit $\left(\mathrm{NH}_{4}\right)_{2} \mathrm{SO}_{4}$ zu einer Fällung des ${ }^{14} \mathrm{C}$-DNA-Antikörperkomplexes kommt und damit nach Maßgabe der im Serum vorhandenen DNA-Antikörper eine unterschiedliche Konzentration an radioaktiver DNA im Überstand verbleibt. Die Bestimmung der DNA-Antikörper erfolgte im Eppendorf Mikrolitersystem. Der Versuchsansatz enthielt: $10 \mu 1{ }^{14}$ C-DNA-Lösung (spez. Aktivität: $39,2 \mu \mathrm{Ci} / \mathrm{mg}$, dies entspricht 0,1 $\mu \mathrm{g}$. DNA $(7000 \mathrm{cpm}) ; 40 \mu 10,1 \mathrm{~mol} / 1$ Tris-HCl-Puffer $\mathrm{pH} 7,4,0,15 \mathrm{~mol} / 1$ $\mathrm{NaCl} ; 50 \mu 1$ Serum. Er wurde eine Stunde bei $37{ }^{\circ} \mathrm{C}$ und dann eine Stunde bei $4 \mathrm{C}$ inkubiert. Daraufhin wurden $100 \mu 1$ kalte gesättigte $\left(\mathrm{NH}_{4}\right)_{2} \mathrm{SO}_{4}$ Lösung zugesetzt und gemischt. Nach 30minütiger Inkubation im Eisbad erfolgte die Zentrifugation der Probe bei $16000 \mathrm{~g}$, 2,5 Minuten (Eppendorf Tischzentri- 
fuge), anschließend wurden 0,1 ml des Überstandes zur Aktivitätsbestimmung im Flüssigkeitsszintillationszähler entnommen und $1,3 \mathrm{ml}$ dest. Wasser und $8,7 \mathrm{ml}$ Aquasol (NEN) zugegeben. Der Gehalt an DNA-Antikörpern des jeweiligen Serums wurde in prozentualer DNA-Bindung bezogen auf die zum Test eingesetzte ${ }^{14} \mathrm{C}$-DNA, ausgedrückt. Die prozentuale DNA-Bindung wurde wie folgt berechnet: $\frac{T-2 U}{T} \times 100=\%$ DNA-Bindung,

wobei T (in Imp./min) der eingesetzten Gesamtradioaktivität und U (in Imp./min) der Radioaktivität in $0,1 \mathrm{ml}$ Uberstand entspricht. Von Heicke \& Lemmel (6) wurde dabei ein Normbereich von 0\%-20\% DNA-Bindung gefunden. Die Angabe von \% DNA-Bindung entspricht in dem verwendeten Ansatz damit gleichzeitig der Bindung von ${ }^{14} \mathrm{C}$-DNA in ng pro Ansatz.

Einfluß von DNase I auf die DNA-Antikörperbestimmung

Die DNA-Antikörperbestimmung wurde wie oben beschrieben durchgefuhrt. Dic Bestimmung erfolgte in Parallelansätzen mit demselben Serum. Zum einen mit dem oben beschriebenen Versuchsansatz, zum anderen wurde jedoch mit dem Tris-HCl-Puffer pH 7,4 zusätzliche DNase I zugesetzt. Die Endkonzentration an DNase I bezogen auf den Gesamtansatz betrug $20 \mu \mathrm{g} / 1$.

\section{Ergebnisse und Diskussion}

Mit der von Heicke \& Lemmel (6) angegebenen Untersuchungsmethode zur Bestimmung von DNA-Antikörpern im Serum wurden Patienten mit der klinisch und bioptisch gesicherten Diagnose Lupus ery thematodes untersucht. Wie von ihnen (6) beschrieben, läßt sich bei einigen Patienten kein erhöhter DNA-Antikörpergehalt, das heißt mehr als $20 \%$ Antikörper-Bindung, nachweisen. Unsere Untersuchungsgruppe bestand aus 12 Patienten mit erhöhter Bindung und aus 15 Patienten, deren DNA-Antikörpergehalt sich im Normbereich bewegte (Abb. 1).

Bei der Bestimmung der DNase-Gesamtaktivität im Serum mit der empfindlichen Adsorptionsmethode an Nitrocellulosefilter nach Geiduschek \& Daniels (14) zeigte sich kein signifikanter Unterschied im DNase-Gehalt des Serums zwischen LE-Patienten mit erhöhtem DNA-Antikörpergehalt und solchen, deren Werte im Normbereich lagen (Tab. 1).

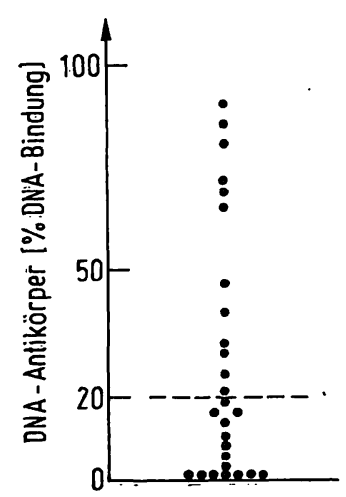

Abb. 1. Die Abbildung 1 zeigt den unterschiedlichen DNA-Antikörpergehalt verschiedener LE-Seren, ausgedrückt in \% DNA-Bindung ( $=\mathrm{ng}{ }^{14} \mathrm{C}$-DNA Bindung). Die Bestimmung der DNA-Antikörper erfolgte wie in Material und Methoden beschrieben im Eppendorf Mikrolitersystem. Jeder Punkt entspricht dem Wert einer Serumprobe. Es handelt sich nur um klinisch und bioptisch gesicherte LE-Patienten. - - gibt die obere Grenze des Normbereichs an.
Tab. 1. DNase-Gesamtaktivität in LE Seren (MembranfilterTechnik). Vergleich der DNase-Gesamtaktivität von LE Seren zwischen Patienten mit erhöhtem DNA-Antikörpergehalt (mehr als 20\% DNA-Bindung) und solchen mit einem DNA-Antikörpergehalt im Normbereich (weniger als 20\% DNA-Bindung). Die Bestimmung der DNase-Gesamtaktivität erfolgte mit der Adsorptionsmethode an Nitrocellulosefiltern.

\begin{tabular}{|c|c|c|}
\hline & $\begin{array}{l}\text { Patienten } \\
\text { mit erhöhtem } \\
\text { DNA-Antikörpergehalt } \\
\mathrm{n}=5\end{array}$ & $\begin{array}{l}\text { Patienten } \\
\text { mit niedrigem } \\
\text { oder fehlendem } \\
\text { DNA-Antikörpergehalt } \\
\mathrm{n}=8\end{array}$ \\
\hline \multirow[t]{2}{*}{$\begin{array}{l}\text { DNase-Aktivität } \\
\text { in \% nicht- } \\
\text { adsorbierter } \\
\text { DNA }(\bar{x} \pm s)\end{array}$} & $39,80 \pm 18,05$ & $32,12 \pm 20,92$ \\
\hline & $t=0,63$ & $p \gg 0,1$ \\
\hline
\end{tabular}

Diese Befunde schließen jedoch unterschiedliche DNaseAktivitäten bei beiden Patientengruppen nicht aus. Wenn Patientenseren mit unterschiedlichem DNA-Antikörpergehalt einem DNase I Reaktionsansatz zugesetzt wurden, so führte das zu einer Verminderung der DNase-Aktivität. Wir beobachteten eine Abnahme der Aktivität um Werte zwischen $63,5 \%$ und $86,8 \%$, bezogen auf den Ansatz ohne Serumzugabe. Dies spricht für unterschiedliche Aktivitäten von DNase-Inhibitoren in den jeweiligen Seren, was übereinstimmt mit den Befunden von Frost \& Lachmann (19), die besonders bei Patienten mit LE unterschiedliche Mengen von DNase-Inhibitoren nachwiesen. Der Nachweis von DNasen mit Hilfe des microdisc-elektrophoretischen DNase-Nachweises im DNAPolyacrylamidgel dagegen wird nicht durch gleichzeitig im Serum vorhandene DNase-Inhibitoren beeinflußt. Wie Abbildung 2 a zeigt, finden sich dabei hauptsächlich zwei unterschiedliche Enzym-Aktivitäten im menschlichen Serum. Beıde sind bei pH 7,4 aktiv und benötigen 2 wertige Kationen. Mißt man die aus dem ${ }^{3} \mathrm{H}$-DNA haltigen Gel während der Inkubation herausdiffundierende Radioaktivität der DNA-Bruchstücke, so stellt auch sie ein Maß für die DNase-Aktivität in den verschiedenen Gelzonen dar (Abb. 2b). Die mit beiden Methoden erhaltenen Kurven entsprechen einander. Die Kontrolle des Nachweises von DNasen in DNA-haltigen Polyacrylamidgelen durch Anfärbung der im Gel verbliebenen DNA (Abb. 2a) mit Hilfe des radioaktiven DNase-Nachweises in ${ }^{3} \mathrm{H}$-DNA-Poly acrylamidgelen (Abb. 2b) nach der Auftrennung von Serum mit der Disc-Elektrophorese ist notwendig, da unter Umständen zusätzliche Banden durch mit Gallocyanin-Chromalaun anfärbbare Bestandteile des Serums vorgetäuscht werden können (10).

Weitere Untersuchungen führten wir wegen des geringeren methodischen Aufwandes mit der Färbemethode durch. Die dabei gewonnenen Werte zeigen einen signifikanten Unterschied $(t=-3,39 ; p<0,01)$ zwischen der DNase-Aktivität im Serum von Patienten mit erhöhtem 


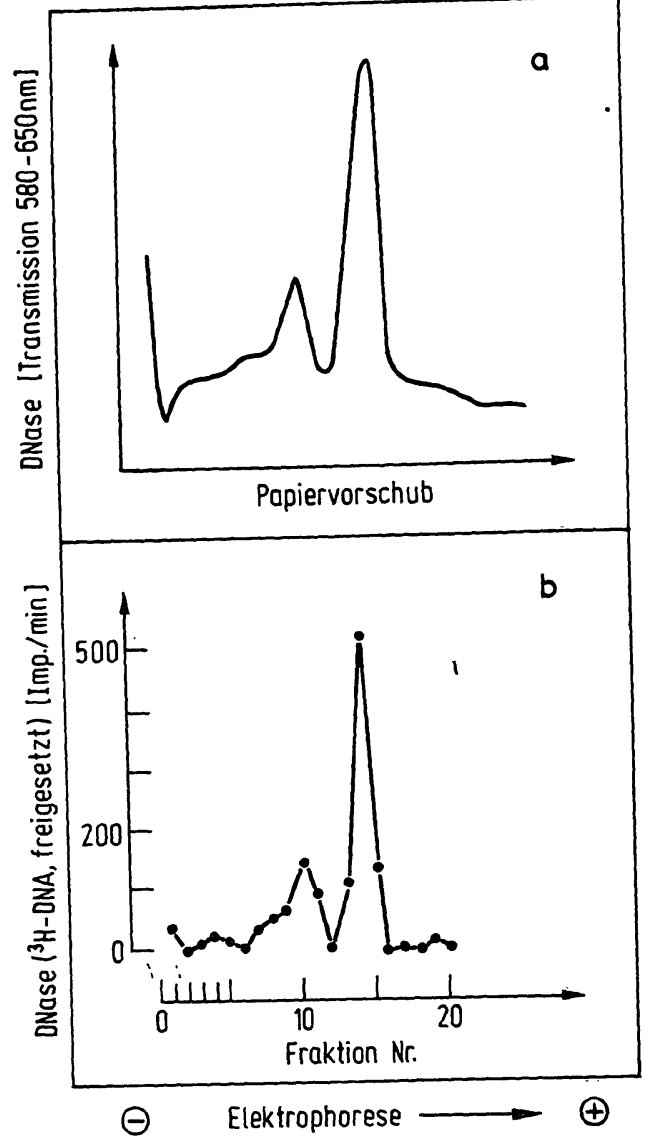

Abb. 2. Bestimmung der DNase-Aktivität in LE-Seren mit dem micro-disc-elektrophoretischen DNase-Nachweis:

a) Densitometerkurve eines DNA-Polyacrylamidgels nach Trennung und Nachweis von Serum DNasen. Versuchsbedingungen s. unter Material und Methode. b) Die gleiche Probe wie in a) wurde in einem ${ }^{3} \mathrm{H}-\mathrm{DNA}$ Polyacrylamidgel aufgetrennt.

DNA-Antikörpergehalt zu solchen mit DNA-Antikörpern im Normbereich. Die DNase-Aktivität ist bei der ersten Gruppe eindeutig niedriger (Abb. 3), sie liegt dabei in dem schon von Kurnick (9) angegebenen Bereich.

Dieser Befund einer signifikant höheren DNase-Aktivität im Serum von LE-Patienten mit DNA-Antikörpern im Normbereich gegenüber solchen mit erhöhtem DNAAntikörpergehalt könnte den Nachweis von niedrigeren DNA-Antikörperkonzentrationen bei der ersten Gruppe von LE-Patienten erklären. Wie von Geisert et al (11) beschrieben, ist die DNA-Antikörperbindung stark vom Molekulargewicht der angebotenen DNA abhängig, dies bedeutet, daß bei niedrigem Molekulargewicht der DNA im anti-DNA-Antikörpernachweis ein zu geringes DNABindungsvermögen vorgetäuscht und damit ein zu niedriger DNA-Antikörpergehalt bestimmt wird. Beim Antikörpernachweis erfolgt eine Inkubation der DNA mit den zu untersuchenden Seren unter Bedingungen, die eine Aktivität der Serum-DNasen ermöglichen. Dabei könnte die angebotefie DNA teilsweise abgebaut werden und so ein zu niedriger Wert für den anti-DNA- Antikörpergehalt dieses Serums bestimmt werden. Zusatz von DNase in den Reaktionsansatz zum Antikörper-

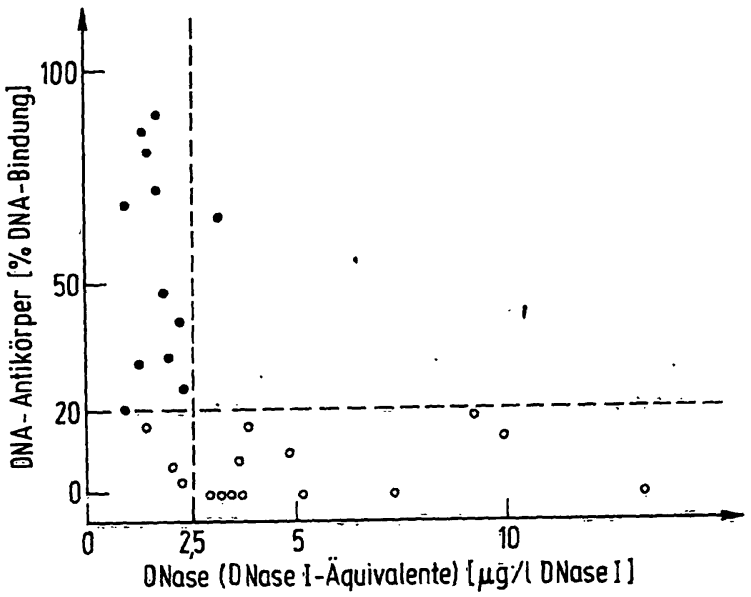

Abb. 3. Bestimmung der DNase-Aktivität von LE-Seren mit dem micro-disc-elektrophoretischen DNase-Nachweis in DNA-Poly acrylamidgelen. Versuchsbedingungen s. unter Material und Methode.

- Seren mit mehr als $20 \%$ DNA-Bindung

- Seren mit weniger als $20 \%$ DNA-Bindung.

Patienten mit erhöhtem DNA-Antikörpergehalt zeigen eine durchschnittliche DNașe-Aktivität von $\overline{\mathrm{x}} \pm \mathrm{s}=$ $1,65 \pm 0,65 \mu \mathrm{g} / 1 \mathrm{im}$ Gegensatz zu der durchschnittlichen Aktivität von $\bar{x} \pm s=5,03 \pm 3,39 \mu \mathrm{g} / 1$ DNase I Äquivalenten bei Patienten mit einem DNA-Antikörpergehalt im Normbereich. Der Unterschied ist $(t=-3,39$; $p<0,01$ ) signifịkant.

nachweis müßte unter dieser Voraussetzung niedrigere Werte ergeben. Dies ist jedoch nicht der Fall (Táb. 2). Dieses Ergebnis erklärt sich durch Hemmung der zuggesetzten DNase durch im Serum befindliche Inhibitoren. Aus dieser Tatsache, daß die dem Ansatz zur DNA-Antikörperbestimmung zugesetzte DNase die DNA-Antikörperbestimmung nicht beeinflußt, kann gefolgert werden, daß bei erhöhtem Serum-DNase-Spiegel es bei der DNAAntikörperbestimmung nicht zu einem Abbau der zugesetzten radioaktiven DNA durch diese Serum-DNasen kommt. Demzufolge erscheint es unwahrscheinlich, daß der niedrigere DNA-Antikörpergehalt bei einigen LE-Seren nur darauf zurückführen ist, daß es aus methodischen Gründen zu einer scheinbar zu niedrigen Bestimmung von DNA-Antikörpern in Seren von LE-Patienten mit erhöhtem Serum-DNase-Spiegel kommt. Es ist hingegen möglich, daß DNasen schon bei der Bildung von DNAAntikörpern im Organismus eine Rolle spielen und zwar dergestalt, daß die Antikörper-Bildung durch höhere

Tab. 2. Bestimmung des DNA-Antikörpergehalts von LE-Seren in Parallelansätzen mit und ohne Zusatz von DNase (Endkonzentration $20 \mu \mathrm{g} / 1$ ) Angaben in \% DNA-Bindung. Bestimmung des DNA-Antikörpergehalts siehe unter Material und Methoden.

\begin{tabular}{lcc}
\hline Probe & ohne DNase & mit DNase \\
\hline 1 & 3,3 & 0,0 \\
2 & 23,0 & 23,9 \\
3 & 59,8 & 56,1 \\
4 & 46,0 & 46,6 \\
\hline
\end{tabular}


DNase-Konzentrationen verhindert wird. Dies ist ein $\mathrm{Zu}$ sammenhang, der ähnlich schon von Frost \& Lachmann (19) gesehen wurde, die allerdings das Verhalten von DNase-Inhibitoren untersuchten. Sie fanden, daß in vielen Fällen ein erhöhter Gehalt an antinukleären Faktoren mit einer Erhöhung der Serum-DNase-Inhibitoren einhergeht und folgerten daraus, daß der erhöhte Inhibitorgehalt eine hinreichende, jedoch keine notwendige Bedingung zur Antikörperbildung darstellt. Dies ist nach den vorliegenden Befunden dahingehend zu ergänzen, daß möglicherweise durch einen erhöhten DNaseSpiegel die Bildung von DNA-Antikörpern direkt gehemmt wird. Auf welcher Stufe DNasen die DNA-Antikörperbildung beeinflussen, ist nach den vorliegenden Befunden offen. Es besteht jedoch auch die Möglichkeit, daß die Aktivitätserhöhung der DNase Folge eines anderen Vorgangs (z. B. Virusinfektion) ist, der unab- hängig davon auch die DNA-Antikörperbildung beeinflußt, so daß aus der beobachteten Korrelation keine direkte kausale Beziehung abzuleiten ist.

Bei der Bewertung von DNA-Antikörperbestimmungen zur Diagnose des LE sollte jedoch vor allem bei negativem Ausfall eine mögliche Erhöhung der Serum-DNaseAktivität in die Úberlegung einbezogen werden, da bei hohen Serum-DNase-Aktivitäten auch bei gesichertem LE der anti-DNA-Antikörpergehalt des Serums nicht erhöht sein muß.

\section{Danksagung}

Wir danken der Deutschen Forschungsgemeinschaft für die Gewährung von Sachmitteln, der Firma Mack, Illertissen, für die großzügige Überlassung von Herings-DNA, sowie Fräulein $R$. Fuchs und Herrn cand. chem. E. Metzmann für die ausgezeichnete Mitarbeit.

\section{Literatur}

1. Holman, H. R. \& Kunkel, H. G. (1957), Science 126, 162-163.

2. Casals, S. P., Frion, G. J. \& Myers, L. L. (1964), Arthritis and Rheumatism 7, 379-390.

3. Kofler, D., Carr, R., Aquello, V., Thoburn, R. \& Kunkel, H. G. (1971), J. Exp. Med. 134, 294-312.

4. Deicher, H. R. G., Holman, H. R. \& Kunkel, H. G. (1959), J. Exp. Med. 109, 97-114.

5. Harbeck, R. J., Bardana, E. J., Kohler, P. F. \& Carr, R. J. (1973), J. Clin. Invest. 52, 789-795.

6. Heicke, B. \& Lemmel, E. M., in Vorbereitung.

7. Heicke, B. \& Lemmel, E. M. (1974), diese Z. 12, 46.

8. Wroblewski, F. \& Bodansky, O. (1950), Proc. Soc. Exp. Biol. Med. 74, 443-445.

9. Kurnick, N. B. (1953), Arch. Biochem. 43, 97-107.

10. Zöllner, E. J., Heicke, B. \& Zahn, R. K. (1974), Anal. Biochem. 58, 71-76.

11. Geisert, M., Heicke, B. \& Metzmannn, E. Nucleic Acid Res. Zur Veröffentlichung eingereicht.
12. Zahn, R. K., Tiesler, E., Kleinschmidt, A. K. \& Lang, D. (1962), Biochem. Z. 336, 281-298.

13. Hönig, W., Zahn, R. K. \& Heitz, W. (1973), Anal. Biochem. $55,34-50$.

14. Geiduschek, E. P. \& Daniels, A. (1965), Anal. Biochem. 11, 133-137.

15. Siebert, G. in Handbuch der Physiologisch- und Pathophysiologisch-Chemischen Analyse (Lang, K., Lehnartz, E., Hoffmann-Ostenhof, O. \& Siebert, G., Hrsg.) Bd. 6, Teil B, 1061-1103, Springer Verlag, Berlin, Heidelberg, New York.

16. Zöllner, E. J., Müller, W. E. G., Zahn, R. K., Brehm, G. \& Korting, G. W. (1971), Klin. Wochenschr. 49, 1290-1294.

17. Boyd, J. B. \& Mitchell, H. K. (1965), Anal. Biochem. 13, $28-42$.

18. Neuhoff, V. (1968), Arzneimittelforsch. 18, 35-39.

19. Frost, G. P. \& Lachmann, P. J. (1968), Clin. Exp. Immunol. $3,447-455$.
Dr. E. J. Zöllner

Physiologisch Chemisches Institut der Johannes Gutenberg Universität 65 Mainz

Johann Joachim Becher Weg 13 GERMANY 